ANDRZEJ SARNACKI, S.J. ${ }^{1}$

\title{
THE DECAY OF AMERICAN CULTURE? PITIRIM SOROKIN'S VIEW ON THE RELEVANCE OF THE SEX REVOLUTION
}

\begin{abstract}
The undeniable shift in American culture over last decades, regarding the values and self-identity of its citizens, has been a subject of extensive inquiries. While there have been studies of many problematic developments, such as the erosion of social capital or the rise of narcissism, not much attention has been dedicated to the meta-perspective of the ongoing transformation and self-destructive mechanisms of modern social and cultural agendas. Pitirim Sorokin has pointed out the importance of a dominant attitude towards sex, which virtually predestines the future of a given society. Conservative in its outlook, his view is worth taking into consideration, especially due to its references to the historical data of past civilizations. This perspective is especially relevant for the modern cultural and scientific paradigm, which regards contestation of sexual expansion as unjustified and even illegitimate. Sorokin's perspective on "sexual anarchy" might prove to be a valid one in regard to Western civilization.
\end{abstract}

Key words: Pitirim Sorokin, sexual revolution, sexual anarchy, cultural decadence

In his bestselling book The Fifth Discipline, Peter Senge discusses the common tendency of the human brain to stay oblivious to incremental, superimposing changes, registering only those which are very visible and sudden. ${ }^{2}$ Many serious changes undergo a silent, unnoticeable phase for most minds, before they reach a point of abrupt explosion that becomes obvious to all perceptions. Yet a few are able to detect the looming shape of the new land at its dawn and foresee the direction, and maybe the

${ }^{1}$ PhD; Jesuit University Ignatianum in Kraków; andrzej.sarnacki@ignatianum.edu.pl.

${ }^{2}$ P. Senge, The Fifth Discipline, New York 1994, p. 112. 
consequences of such change. To those observant and intuitive minds belongs that of Pitirim Sorokin, who in 1956 published a book entitled The American Sex Revolution, in which he predicted the vast cultural change that was going to mark the 1960s and influence all aspects of life in the following decades. The perspective of Sorokin is worth consideration, because it represents not just old-school moralising, but a scrutiny over a serious social and cultural change before the epoch of the expansion of ideological arguments. This narrative is relatively sparce in its argumentation, and could be better understood only against the sequel to sensate and ideational culture, as presented in Sorokin's magnum opus, namely Social and Cultural Dynamics, published a year later. ${ }^{3}$

This article is not a presentation of Sorokin's concept in full, but limited to his view on the meaning of a change in perception of the place of sexuality in a society. His views will be presented in the context of other shifts in American culture, already described as weakening social capital, the rise of narcissism, secularization and cultural Marxism. These will be presented only in a brief manner. Sorokin's view on the sexual revolution has already been presented in detail by Russell Nieli. ${ }^{4}$ Moreover, an evaluation of his work, as well as a broader presentation of Sorokin's concept of sensate and ideational culture have been published in two other articles I have written. ${ }^{5}$ The contribution this article aims to make, however, is to present an analysis of Sorokin's work, and to confirm, from a 60-year perspective, his intuition of the value of sexuality in our civilization. The negative aspects of this development seem to be overlooked in the scientific world, as well as in general literature or media, although the civilization in question has been showing signs of decadence.

\footnotetext{
${ }^{3}$ P. Sorokin, Social and Cultural Dynamics, Boston 1957.

${ }^{4}$ R. Nieli, "Critic of the Sensate Culture: Rediscovering the Genius of Pitirim Sorokin", Political Science Reviewer, vol. 35, no.1 (2006), pp. 264-379, https://isistatic.org/ journal-archive/pr/35_01/nieli.pdf.

${ }^{5}$ A. Sarnacki, Aktualność Piotra Skargi - o niebezpiecznych aspektach społeczno-kulturowych, w: M. Chrost, I. Nowakowska-Kempna, Rzecz o dziele Piotra Skargi SJ, Kraków 2012, pp. 245-256; and A. Sarnacki, „Peryferyjność monastycyzmu? Kameduli i cykliczność kultur Pitirima Sorokina", Anthropos?, nr 25 (2016), pp. 30-43, http://www.anthropos.us.edu.pl/texty/sarnacki.htm.
} 


\section{CRITICAL ASSESSMENTS OF THE $20^{\text {TH }}$ CENTURY SHIFT}

Sorokin's observation is also interesting from the perspective of contemporary prevalent narratives, with their axioms and dogmas that do not recognise any other evidence than those commonly accepted in the scientific community and Western culture. The very absence of Sorokin's thought in modern discussion is caused by his unorthodox, and seemingly old-fashioned precepts, which would oppose the mainstream school of thought. Nevertheless, his critique of the shift in American traditional values and his appeal against the self-destructive forces of modernised culture, are worthy of cognizance, due to their original angle, which is empowered by the metahistorical context of Sorokin's analysis. Almost 60 years later, a careful reader of this investigation will be left wondering whether a prophet or an eccentric drifter of the scientific world drew these conclusions.

To begin with, there is no doubt that, during recent decades, American culture has been undergoing a momentous change. Formerly associated with a dream of endless opportunities, society has been showing signs of decadence. Pure faith in economic success and social promotion through hard work, honesty and responsibility, has become weakened through too many examples of corruption, political cynicism, or contrary standpoints. Before turning to Sorokin's analysis for the causes of the crisis, it is worth mentioning other works that address the issue of problematic changes in the USA. This is not an extensive and systematic list of authors, but rather a few examples that illustrate a widespread sense of a cultural shift.

In his book published in 2000, Bowling Alone, the renowned American sociologist Robert Putnam observes the decline of social capital, which is based on trust and reciprocity. The strength of social capital depends on the magnitude of mutual trust within a particular society, something that makes people feel bonded, empowered, and happy. The observation of its erosion first relates to the fact that many organisations, such as clubs, political groups or neighbourhood networks are no longer being continuously revitalised by new members. For decades, the characteristic of American social strength and ability of mobilization was referred to as an exuberance of social activities, among them churches, garden clubs and bowling leagues. ${ }^{6}$ Although the number of people bowling has increased over the

${ }^{6}$ R.D. Putnam, Bowling Alone. The Collapse and Revival of American Community, New York 2000, p. 16. 
last 20 years, the number of leagues has declined. People bowl alone and their individual leisure time is supported by the development of technology. Although the growth of social media networks draws in millions of people, its superficiality is causing more isolation.

As the sense of strong bonds at the community, organisation and institution level is the crucial quality of a dynamic society, which in return empowers it, society is able to manage the problems that need to be solved, be they those related to poverty, marginalization, health care or security. An active participation in different organisations teaches its members the value of community, responsibility and leadership. It gives them a sense of a shared identity and teaches the value of reciprocity. It is reflected in participation in political elections, an ability to cooperate, and the extension of social networks. Social capital in its bridging and bonding aspects, promotes civic virtues, good organisation that starts at the local level, engagement that eradicates the pestilence of incapacitation, brings a sense of community, and empowers the struggle against conformism. Even the job-hunting process depends to a great extent on one's people-network.

Putnam detects a critical shift that has been in progress for the last five decades. In the 1960s "America ... was white, straight, Christian, comfortable, and (in the public square, at least), male." ${ }^{\prime 7}$ At the turn of $20^{\text {th }}$ century, it became clear to every American that this golden age of vibrant communities had dissolved into civic malaise and poor economic prospects. Those who claimed that the average American has become less trustworthy and less civic-minded, outnumbered those who claimed the opposite $(80 \%$ to $12 \%){ }^{8} \mathrm{~A}$ similar opinion surrounds the decline of moral values, the widening of social polarization, the decay and erosion of civic participation and the growth of social disengagement, when people have become disconnected from family, friends, neighbours and institutions.

Society is a vast and polymorphous organism, difficult to define and determine its course, which depends on many variables. Of course every society and culture changes during the course of time, as does the type of civic engagement, along with the growing trend of mobility and multimembership. Putnam carefully examines different aspects of social life, taking into account political and civic participation, religious engagement, connections in the workplace, informal modes of networking, involvement

\footnotetext{
7 Ibid., p. 17.

${ }^{8}$ Ibid., p. 25.
} 
in volunteering organisations and philanthropy events, as well as the general attitude of reciprocity, honesty and trust, only to notice that all sectors of American traditional engagement have suffered from decay and erosion.

For the first two-thirds of the twentieth century a powerful tide bore Americans into ever deeper engagement in the life of their communities but a few decades ago - silently, without warning - that tide reversed and we were overtaken by a treacherous rip current. Without at first noticing, we have been pulled apart from one another and from our communities over the last third of the century. ${ }^{9}$

The reasons for these afflictive changes Putnam describes are born out of many complex factors. The first one is the breakdown of the traditional family unit and loosening of family bonds, reflected in the rising rates of divorce, single-parent families or single widows. Marriage and having children usually translates into time spent in community organisations, mainly church and youth related. The erosion of social capital, which results in a general decline of social connectedness and trust, has also had an impact on the further advancement of interracial separation. Global economic transformation, epitomised by the removal of small shops and business by big corporations and chain-stores, also add to the general social disconnection. Putnam also lists factors like pressures of time and money, suburbanization and electronic entertainment including television, which are partially responsible for the process. In his final remark Putnam underlines the most important cause in generational change, namely the shift in generational succession, due to a declining demographic. ${ }^{10}$

Approaching this change from a psychological perspective, Jean Twenge and Keith Campbell point to the growing and over-present phenomena of narcissism in American culture. ${ }^{11}$ The proliferation of an open pursuit of personal fame and glamour could be understood as psychocultural affliction that invades the mentality of parents and children alike. Children treated as princes, kings, members of royalty, stars, geniuses, the best, become inclined to indulgences and immediate reward. At the

\footnotetext{
${ }^{9}$ Ibid., p. 27.

${ }^{10}$ Ibid., pp. 277-284.

${ }^{11}$ J.M. Campbell, W.K. Twenge, The Narcissism Epidemic: Living in the Age of Entitlement, New York 2009.
} 
same time, there are role reversals and a loss of parental authority, when children became partners, and the argument of "because I said so" has become unthinkable. Then overprotecting mothers and "helicopter parenting" have became the model in the over-psychologised upbringing of children, which often leaves the parents confused and acting irresponsibly. Children are rewarded for everything, and in the contrary to the common sense and adult world of market competition, they are daily reassured that coming in last place is as good as coming in first. Self-centred people do not gain just a confidence and high self-esteem, but become divorced from reality by overconfidence, egotism and a conviction of due entitlement. A "winning-attitude" does not set boundaries of respect or discipline, but encourages a futile quest for fame, and possibly a big circle of "friends" in social media. Social networking is the perfect space for narcissistic people broadcasting themselves and living their second life in a virtual world of self-creation. ${ }^{12}$

As the most superficial part of American culture, narcissistic values are conveniently carried around the world in pop music, movies, television, and, increasingly, in the Internet. The media sources smoothly glamorize the narcissistic ethos, showing its shiny surface of prosperity and self-glorification without the down sides of alienation and social breakdown. ... Narcissism is the fast food of the soul. It tastes great in the short term, has negative, even dire, consequences in the long run, and yet continues to have widespread appeal. ${ }^{13}$

Culture has become colonised by phantasmagorias of egoistic individuals obsessed with self-admiration, exhibitionism, an eternal youth fixation, and a drive to be special, unique and amazing. Such attitudes are expressed in slogans of "believing in yourself", "finding your own voice", "feeling good about yourself", having "a positive self-image", etc. Initially well-intended against a "not good enough" upbringing, as the need of a healthy self-esteem and acknowledgment of fundamental equality, they have become a radical departure from the past, replacing the culture of modesty and service to others. The growing concern regarding physical appearance and having a "hot look" have resulted in the popularity of plastic surgery and modelling contests. Modern individuals seek attention at any

\footnotetext{
12 Ibid., p. 109.

${ }^{13}$ Ibid., p. 259.
} 
price, paying homage to a semi-religious worship of celebrities surrounded by a crowd of paparazzi, propagated by enormous business of celebrity gossip magazines and TV programs. It is also a religion of Santa Claus, a figure who is better than God: whereas God demands an effort to be good and distinguishes between sinful and meritorious deeds, Santa takes all people as good and worthy of receiving a gift. Even religious organisations mirror this trend, by the growth of "prosperity Gospel" churches, focused on self-admiration and God unconditionally inclining to one's wishes.

The authors see direct impact on such attitudes in the social processes of the 1960s, when individual rights and liberties gained a historical momentum, while self-improvement became a self-admiration. The drive of the pleasure principle is a destructive behaviour that has short-term benefits and long-term costs. In American culture the immunity to narcissism has weakened, with a growing encouragement to focus on own needs, personal success, and a tolerance of arrogance. ${ }^{14}$ As a result they observe the proliferation and upsurge of materialism, a painful unacceptance in the case of low-standard economic conditions, an obsessive focus on ones needs, all of which at the end makes people less happy and more depressed. At the same time, there has been a drastic increase of hostility and violence against both peers and "the other". Cases of ridiculing, aggressive language, cyber-bullying and assault have been on rise, both at schools and at workplaces. The pressure of becoming famous, discovered and rich has made an impact on millions of minds. Artificial relationships and emotional emptiness, a sense of entitlement and inability to sacrifice or do something without calculation, have caused a drop in community services and voluntary activities. ${ }^{15}$

The narcissism epidemic has already had serious consequences. First, there has been a giant transfer of time, attention, and resources from reality to fantasy. Rather than pursuing the American dream, people are simply dreaming. Our wealth is phony, driven by credit and loose lending; this part of the narcissistic dream has already been dashed. Second, narcissism has corroded interpersonal relationships. There has been a switch from deep to shallow relationships, a destruction of social trust, and an increase of entitlement and selfishness. ${ }^{16}$

\footnotetext{
${ }^{14}$ Ibid., pp. 37, 53-60, 128.

15 Ibid., p. 176.

${ }^{16}$ Ibid., p. 276.
} 
These books and many other share a similar concern regarding a substantial change in American culture. There is no shortage of apocalyptic prophesying that see the dissolution of traditional, hitherto indisputable values, as the beginning of the end, as self-destructive mechanisms of entrapped culture. A perfect example could be James Burnham who already claimed in 1964 that liberalism would eventually lead Western society to suicide. ${ }^{17}$ Under the baton of a liberal economy, within the framework of globalization, the traditional perception of hard work, as a certain way of climbing the social ladder and children securing a better future than their parents, has been fading. The transfer of labour oversees has changed the domestic labour market, shifting the labour force towards services, at the same time diminishing their chances to achieve a standard of living higher than the previous generation. The access of women to the labour market and their growing significance as part of the labour force adds another aspect to changes in traditionally understood roles.

Although America has withstood the forces of secularization, the diversification of mostly Christian churches has converged to the economic dynamic, giving birth to a phenomenon of a "religious market". The competition between denominations is regarded as a source of spiritual vitality, when at the same time "religious products" have become more and more alike. This economic analogy has led to a thesis of a religious development specific to the late stage of capitalism. ${ }^{18}$ In its zenith, the socialist school of thought has become relevant as never before in American history.

There is a growing awareness of a political flavour and the influence of cultural Marxism that tends to dominate cultures of values and ideas. In its quest it promotes new assumptions claiming that people should be loyal not to their countries or religions, but to the concept of international brotherhood. Antonio Gramsci in Prison Notebooks talks about a long march through institutions (arts, cinema, media, educational system, papers, etc.), in order to change the way of thinking about patriotism, nation, religion, values, mentality, which is to change the culture from the inside. The task is to remove the barriers of Christendom and Holy Scripture, especially with regards to religious communities, which hold them as

\footnotetext{
${ }^{17} \mathrm{~J}$. Burnham, Suicide of the West: an Essay on the Meaning and Destiny of Liberalism, New York 1964.

${ }^{18}$ L.R. Iannaccone, "The Consequences of Religious Market Structure", Rationality and Society, 3/2 (1991), pp. 156-177.
} 
a source of support and a reference of their identity. Consequently, it is meant to dismantle the family unit, in order that people look for support somewhere else. The concept of the alienation of old values and the creation of new ones is to be found in works of Georg Lukács, with the recurring idea of a drive towards collectivism, where everybody conforms to a collective logic, even if it includes the use of coercion. ${ }^{19}$

These ideas have been realised by critical theory, which is understood as systematic questioning of everything traditional and the deconstruction of old convictions as relative, oppressive, or patriarchal. This went against traditional morality that praised the self-restraint, hard work and puritan mentality, as values of the middle class. Through endless repetition, all history became understood as a time of sexual repression and oppression. In the era of the baby-boomers, change meant also a commercialization and commodification of sexuality, which became a byproduct of the blending of sexuality and the liberal market. Sexual education, free love, the irrelevance of religion, the outdatedness of monogamy and family as middleclass, and the pervasiveness of permissiveness, became an important part of the de-Christianization of the West.

\section{SOROKIN'S VIEW ON THE SYMPTOMS}

\section{AND GRAVITY OF CURRENT CULTURAL CHANGE}

Sorokin's unique standpoint consists in drawing attention to the significance of the sexual revolution in the 1960s, as the substantial aspect of cultural and social change. Unlike the majority of later academics and commentators, who acknowledge and glorify the central role of sex in social emancipation, Sorokin in his critical analysis claims that the new sexual paradigm endangers the very substance of society and is the sign of its decadence. ${ }^{20} \mathrm{His}$ analysis of social changes in all known historical civilizations brings him to conviction of the importance of the sexual factor in the fate of a society. The perspective of his analysis does not refer to human rights or the idea of inevitable progress, as to the historical evidence

${ }^{19}$ G. Lukács, The Theory of the Novel, Cambridge, Massachusetts 1971 or History and Class Consciousness. Studies in Marxist Dialectics, Cambridge, MA 1971.

${ }^{20}$ P. Sorokin, The American Sex Revolution, Boston 1956, pp. 16-17. 
of constructive and destructive forces in known civilizations. The common pattern of events suggests that social and political anarchy has been always paired with sexual anarchy. This regularity is not that new, as it might be thought. The morals of a society decline when its ethical imperatives and codes become regarded as irrelevant and relative, and changeable at will for any particular interest or desire. Within this framework the values of womanhood and manhood, the concepts of motherhood, fatherhood, marriage and family become a kind of ornamentations, regarded as ignoble and obsolete. ${ }^{21}$ The same applies to the concept of honour, religion or politics.

According to Sorokin, all historical disturbances and riots are the consequence of sexual anarchy.

... evidence from almost every important revolution and social disturbance from the oldest Egyptian upheaval c. 2500 B.C. to the present time show the close connection between sexual and sociopolitical revolutions. ${ }^{22}$

This is due to the revolutionary deconstruction of an existing system of values, institutions and order. The upper classes usually have their leading role in moral disintegration preceding events. These signs of decadence are known from all down-hill periods of Assyrian, Babylonian, Chalcedonian, Chinese, Cretan, Egyptian, Etruscan, Hellenistic, Roman or Russian history. The same pattern could be found in European history, such as in the Dutch Revolt of 1663 with its brutality and outburst of sexual activity, in the period of Italian Renaissance's sexualization, or in the French Revolution proclaiming divorce laws, lowering the age of marriage to 13 for girls and 15 for boys, with the consequences of the skyrocketing of babies born out of wedlock and abandoned, the rise of the number of prostitutes, orgies, debauchery and an acceptance of scandalous behaviour among children. ${ }^{23}$ Similar manifestations may be found in France, Austria and Germany during the disturbances in the $19^{\text {th }}$ century.

A rise of the significance of sexuality always has led to an increase in divorce, premarital and extramarital sex being regarded as normal, marriage being viewed as a "social burden", to the rule of sensualism, licentiousness,

\footnotetext{
${ }^{21}$ Ibid., p. 89.

22 Ibid., p. 102.

${ }^{23}$ Ibid., pp. 100-101.
} 
depravity, hedonism, sadism, as well as to decreasing birth rates, thus depopulation. It brings demoralization and a rapid change in one's life-style that becomes hedonistic. There will be trends towards the emancipation and masculinization of women, the effemination of men, a dissolving of the sacredness and inviolability of marriage together with growing irreligiosity, vulgar sensualist ethics, prostitution, and a growing social sense of entitlement and passive expectation that the state will provide. When housewives become liberated, their preoccupation will be love affairs. Even the change of clothes from discreet to revealing, from modest to immodest will become common. ${ }^{24}$ The change in sexual behaviour has a significant impact on the arousal of sexual appetite, on one's philosophical and moral outlook, as well as on one's aesthetic, social, scientific or religious beliefs. ${ }^{25}$

That proliferation of sexualization goes in parallel with the shift of other norms and attitudes characteristic to secularization. What was once regarded as demoralising now stands for progress and freedom. In the arts, the main focus is transferred from standard, normal daily activities, to the subnormal, abnormal, pathological, as well as emotionally and mentally deranged phenomena. Love, once pure and noble, has become portrayed as perverse, vulgar, exotic or brutal. Writers or film directors have been paying tribute to sex in its ever more vivid expressions, mingled with psychoanalytical interpretations. In addition, the arts have become shifted from the religious and ascetic to the erotic and obscene. Song lyrics have become erotically charged to an enormous degree, and are played in night clubs intoxicated by an alcoholic-saturated atmosphere. ${ }^{26}$

All spheres, including social science, are invaded by sexuality. There is observable sex-mindedness in psychology, sociology, anthropology and other disciplines, which Sorokin disregard as producing

swaddling and toilet-training philosophies of history, according to which the manner of tending infants is the decisive factor which determines the culture, institutions and destiny of peoples and nations. ${ }^{27}$

\footnotetext{
${ }^{24}$ Ibid., p. 95.

25 Ibid., p. 15.

${ }^{26}$ Ibid., pp. 21-37.

${ }^{27}$ Ibid., p. 40.
} 
The Freudian pleasure principle and sex drive embodied by groups of psychoanalysts and psychiatrists have replaced the old faith in good and bad spirits affecting every human being. Sorokin also anticipates the plan of early sexual education for children, and the growth of hedonistic, warmly approved ethics in many religious denominations. This produces a religious schizophrenia, blurring previously accepted boundaries. The shallowness of new constructs is adopted and carried on by "sophisticated barbarians", and "the open-minded and empty-minded midgets of the professions". ${ }^{28}$ Sorokin disregards the opinion purportedly that a sexually free society is healthier and happier than one which is restrictive, as unscientific. ${ }^{29}$ He sees no evidence that the lifting of the posit that suppression of libido relieves negative tension, thus providing healthier and mentally more stable society. On the contrary, the statistics confirm a proliferation of neuroses and psychoses, as well as an impairment of cognitive, intellectual processes. The excessive pursuit of sexual pleasure causes an inner chaos and moral deterioration, and pushes one towards a violation of moral imperatives.

Sorokin sees a sex-obsessed society as sex-diseased, which diminishes its ability to make sacrifices and to deal with problems, such as defence and survival. Its lot can be compared to the history of many royal, aristocratic families, whose loss of leadership and biological extinction was due to debauchery followed by sterility. ${ }^{30}$ This moral shift radically diminishes the creative capacity of a society and its vitality. Its spread is already a sign of the illness of its condition, as a revolution can "conquer only governments and groups already debilitated and demoralized through their own deeds." ${ }^{131}$ Contrary to widespread convictions, Sorokin claims that "civilized societies which have most strictly limited sexual freedom have developed the highest cultures." ${ }^{32}$ When its moral codes lose their validity, a decline happens within three generations.

Christianity on the other hand, is anti-materialistic, anti-sensualistic and anti-erotic system of values, guarded by commandments, and curbing

\footnotetext{
28 Ibid., p. 53.

${ }^{29}$ Ibid., p. 65.

${ }^{30}$ Ibid., p. 79.

31 Ibid., p. 104.

32 Ibid., p. 111.
} 
the prevailing sexual anarchy. ${ }^{33}$ Marriage brings an important self-fulfilment for a person, which includes existential and civic maturity and responsibility. This is why in all societies the marital bond has a high status and the condition of the survival of all. Among many, it enables people to deal with differences of the other person that lowers one's level of selfishness. As such, Christianity in times of sexual anarchy becomes the target of all criticism. Sexual continence (word that does not exist in many dictionaries), chastity or faithfulness, become viewed as oddities or ossified survivals of a prehistoric age. They are often portrayed as morally reprehensible, unscientific, and stupid, hence ridiculed and stigmatised. ${ }^{34}$

\section{THE CONSEQUENCES OF THE SEXUAL REVOLUTION}

A revolution changes the power structure at the level of both government and citizens. The transformation of the 1960s and 1970s became a pivotal point of the new course of Western culture. The appearance of the contraceptive pill on the market has taken away social censorship. Unwanted pregnancy, together with the legalization of abortion, quickly found a wide interest. As Bailey puts it, "the birth control pill was central to the behavioral and cultural changes that make up what we still call the sexual revolution." ${ }^{\prime 35}$ Premarital sex, divorce, abortion, contraception, early sexual initiation, the promotion of homosexuality, extra- and premarital sex, pared by declining birth rates have become examples of the sexualization of all spheres. As a part of general individualization, it has brought a different image of family, increased the content of eroticism in movies, newspapers, books, TV shows, song lyrics, commercials, and the popular press.

Sorokin, in his critical and negative view on this upcoming change, objects to its focus on sex, on sexual obsession regarding every aspect of life, on the treatment of sexual misconduct as normal, acceptable, extolling promiscuity, monogamous marriage as obsolete and culturally relative. Once Victorian society lost its social control of sexual life, it demoralised

${ }^{33}$ Ibid., p. 97.

${ }^{34}$ Ibid., p. 44.

${ }^{35} \mathrm{~B}$. Bailey, "Prescribing the pill: politics, culture, and the sexual revolution in America's heartland", Journal of Social History, vol. 30, no. 4 (1997), p. 827. 
the ruling class and introduced to politics liars, double-crossers, and transgressors, unable to be loyal to constitutions.

Still greater has been the deterioration of the family as a union of parents and children, with "fluid marriages" producing a super-abundance of the physically, morally, and mentally defective children, or no children at all. ${ }^{36}$

As already mentioned, Sorokin has no doubts that the development is a harmful one, firstly, in its creative élan. Sexual profligates lose their sensitivity, self-discipline, sense of purpose, or ability to sacrifice, to commit themselves to social demands, and so become incapable of sustainable effort. Instead they extol irresponsible and hedonistic lifestyle that contributes very little, if at all, to society. Sexual obsession diminishes creative potential of any given society and devitalises it, eventually also in its economic realm. Regarding scientists, uncritical of this development, Sorokin has a harsh opinion:

We live in an era of learned intellectual "contractors" who can build philosophical motels but are incapable of constructing Parthenons or cathedrals. ${ }^{37}$

They produce hardly any works of lasting significance.

From the perspective of half a century, one may admit that Sorokin was right in many aspects. In the meantime, sex and pornography became a business commodity, having an enormous impact on media, school education, arts or language. Words like "faithfulness", "chastity" and "sexual continence" have become regarded as suspicious, archaic, and irrelevant. Partnership and free love have replaced promiscuity, when certain expressions have tamed sexual behaviour like "friends with benefits", or sex without obligations/commitment. The rejection of procreation and use of contraception have become planned and responsible parenthood. The only valid and recognised science is the one with positive attitude towards social and cultural sexual transformation. Sexual mores have become pared with positive images of anti-war and pro-peace movements, human rights, especially women's rights, challenging an oppressive system.

\footnotetext{
${ }^{36}$ P. Sorokin, The American . .., p. 132.

${ }^{37}$ Ibid., p. 144.
} 
It is no surprise that 60 years later the attitude of Sorokin would be vastly questioned, and to a much smaller extent supported. As a representative of the former we could mention Nancy L. Cohen and her book Delirium: How the Counterrevolution is Polarizing America. ${ }^{38}$ The suggestive title declares upfront that the blame of the current social tension is on a Christian countermovement that contradicts the achievements of greater sexual freedom. The already classic narrative sees gay marriage, birth control or abortion as rights and the climax of human freedom. In a too-wellknown tone, she depicts their opponents as sex-obsessed defenders of ignorance and backwardness.

On the opposite side of the minority that defends traditional values, one could pay attention to the work of German sociologist Gabriele Kuby. In her book The Global Sexual Revolution: Destruction of Freedom in the Name of Freedom, she holds a view similar to that of Sorokin. ${ }^{39}$ The sexual revolution has changed the metaphysical context of norms, introducing confusion and disorder. Moreover, it is not just a natural development but an imposition of powerful agencies that enforce law and social censure.

The important observation of Sorokin, worthy of further studies says that the sex factor is one of the most important causes of the social development or quiet decay. ${ }^{40}$ When taking too much space in the social and mental spheres, it becomes a destructive force to all other spheres, and the decline could be irreversible. Sorokin declares that most people and leaders of decaying societies were unaware of their cancerous sickness. ${ }^{41}$ When talking about the inevitability of consequences, he thinks that it is possible to change the course of events. However, when sexual debauchery becomes deeply ingrained in culture and institutions, it may be too late to stop the catastrophic drift:

The problem is no longer whether or not mankind has been declining. The problem now is whether mankind will take the last final step in this suicidal course. $^{42}$ 2012.

${ }^{38}$ N.L. Cohen, Delirium: how the Counterrevolution is Polarizing America, Berkeley

${ }^{39} \mathrm{G}$. Kuby, The Global Sexual Revolution: Destruction of Freedom in the Name of Freedom, Kettering 2015.

${ }^{40}$ P. Sorokin, The American . .., p. 120.

41 Ibid., p. 151.

${ }^{42}$ Ibid., p. 147. 


\section{BIBLIOGRAPHY}

Bailey B., "Prescribing the pill: politics, culture, and the sexual revolution in America's heartland", Journal of Social History, vol. 30, no. 4 (1997), pp. 827-856.

Burnham J., Suicide of the West: an Essay on the Meaning and Destiny of Liberalism, New York 1964.

Campbell J.M., Twenge K.W., The Narcissism Epidemic: Living in the Age of Entitlement, New York 2009.

Cohen N.L., Delirium: How the Counterrevolution is Polarizing America, Berkeley 2012.

Iannaccone L.R., "The Consequences of Religious Market Structure", Rationality and Society, 3/2 (1991), pp. 156-177.

Kuby G., The Global Sexual Revolution: Destruction of Freedom in the Name of Freedom, Kettering 2015.

Lukács G., The Theory of the Novel, Cambridge, Massachusetts 1971.

Lukács G., History and Class Consciousness. Studies in Marxist Dialectics, Cambridge, Massachusetts 1971.

Nieli R., "Critic of the Sensate Culture: Rediscovering the Genius of Pitirim Sorokin", Political Science Reviewer, vol. 35, no. 1 (2006), pp. 264-379.

Putnam R.D., Bowling Alone. The Collapse and Revival of American Community, New York 2000.

Sarnacki A., Aktualność Piotra Skargi - o niebezpiecznych aspektach społeczno-kulturowych, in: M. Chrost, I. Nowakowska-Kempna, Rzecz o dziele Piotra Skargi SJ, Kraków 2012, pp. 245-255.

Sarnacki A., „Peryferyjność monastycyzmu? Kameduli i cykliczność kultur Pitirima Sorokina”, Anthropos?, nr 25 (2016), pp. 30-43, http://www.anthropos.us.edu.pl/texty/sarnacki.htm.

Senge P., The Fifth Discipline, New York 1994.

Sorokin P., The American Sex Revolution, Boston 1956.

Sorokin P., Social and Cultural Dynamics, Boston 1957. 